\title{
KONSEP TREP PADA WANDA SEMAR WAYANG KULIT PURWA GAYA SURAKARTA
}

\author{
Yayah Rukiah \\ Program Studi Desain Komunikasi Visual \\ Fakultas Bahasa dan Seni, Universitas Indraprasta PGRI
}

\begin{abstract}
Abstrak. Dalam pewayangan Semar merupakan rokoh yang mempunyai pengaruh besar. Tujuan dari penelitian ini adalah untuk menemukan konsep pada wanda Semar terhadap lakon-lakon yang Semar lakukan. Penelitian ini berfokus pada wayang kulit purwa gaya Surakarta khususnya Semar. Semar dalam pewayangan memiliki lakon bersama Punakawan maupun lakon sendiri, pada setiap lakon Semar menggunakan wanda berbeda. Pada penelitian ini menggunakan metode studi literatur, dimana literatur yang didapat berupa buku, artikel jurnal dan rekaman pertunjukan pada media sosial khususnya tentang Semar yang akan ditelaah untuk mencari konsep antara lakon dan wanda Semar. Rekaman pertunjukan yang digunakan adalah lakon Laire Ismoyo dengan dalang KI Purbo Asmoro. Hasil dari penelitian ini adalah menemukan konsep antara lakon dan wanda Semar yang digunakan, dan konsep yang ditemukan yaitu konsep Trep atau kesesuaian. Konsep kesesuaian penggunaan wanda untuk peran tertentu pada lakon pertunjukan wayang tertentu pula, konsep ini disebut dengan trep. Disebut trep apabila peran wayang Semar dalam suatu lakon pewayangan menggunakan wanda yang sesuai dengan fungsi peran tersebut.
\end{abstract}

Kata kunci: wayang kulit, figur Semar, lakon, wanda

\begin{abstract}
In the Semar puppet is a rock that has a big influence. The purpose of this research is to find the concept of Semar wanda on the plays that Semar did. This research focuses on the Surakarta wayang kulit purwa style, especially Semar. Semar in wayang has a play with Punakawan and the play itself, in each Semar play uses a different wanda. In this study using the literature study method, where the literature obtained in the form of books, journal articles and recordings of performances on social media, especially about Semar will be examined to look for concepts between the play and wanda Semar. The recording of the show used was Laire Ismoyo's play with the puppeteer KI Purbo Asmoro. The results of this study were to find the concept between the play and wanda Semar used, and the concept found was the concept of Trep or conformity. The concept of appropriateness of the use of wanda for certain roles in certain wayang performances, this concept is called trep. Trep is called if the role of Semar puppet in a puppet play uses a wanda in accordance with the function of that role.
\end{abstract}

Keywords: shadow puppets, Semar figures, plays, wanda

Correspondence author: Yayah Rukiah, rukiah.yayah13@gmail.com, Jakarta, Indonesia 


\section{Pendahuluan}

Wayang kulit salah satu warisan adi luhung pada masyarakat Jawa. Wayang purwa adalah perlambang kehidupan manusia di dunia ini (Hardjowirogo 11). Karkono dalam Sunarto mengatakan untuk wayang kulit purwa di Indonesia dikenal dengan beberapa gaya (langgam), antara lain wayang kulit purwa gaya Yogyakarta. Wayang kulit gaya Surakarta (Solo), wayang kulit gaya Banyumasan, wayang kulit gaya Kedhu, wayang kulit gaya Jawa Timuran, wayang kulit Bali, dan wayang kulit gaya Cirebon (Sunarto 97).

Wayang merupakan bahasa simbol kehidupan yang bersifat rohaniah daripada jasmaniah. Jika orang melihat pagelaran wayang, yang dilihat bukan wayangnya, melainkan masalah yang tersirat dalam lakon wayang itu. Wayang purwa dikalangan masyarakat awam lebih dikenal dengan nama wayang kulit, bahkan ada juga yang menamakan wayang kulit purwa. Karena wayang kulit itu berjumlah banyak sedangkan wayang purwa adalah jenis pertunjukan wayang kulit dengan lakon-lakon semula bersumber pada cerita-cerita kepahlawanan India yaitu Ramayana dan Mahabarata (Guritno dalam Aisah 1).

Panakawan merupakan bagian dari dunia wayang yang hanya ada di Indonesia, karena di dalam cerita asli pewayangan di India tidak ada tokoh Punakawan. Sedangkan kesenian wayang sendiri sudah ada sejak sebelum kebudayaan Hindu masuk ke Indonesia dan melekat begitu kuat dalam kebudayaan Jawa. Punakawan tidak ada dalam versi asli mitologi Hindu epik Mahabarata atau Ramayana, Punakawan adalah modifikasi atas sistem penyebaran ajaran agama Islam oleh Sunan Kalijaga, meski pendapat ini masih banyak diperdebatkan (Kresna 17). Dalam kamus bahasa Jawa Panakawan mempunyai arti abdi pengiring, dan bisa juga dengan kata lain yaitu Punakawan (Sudarmanto 224).

Punakawan adalah pamong yang tanggap ing sasmito lan limpat ing grahito (Mulyono 68). Kelompok wayang ini disebut dengan wayang prepat (parepat), karena tokoh-tokoh dalam kelompok ini berjumlah empat yang senantiasa dijadikan kawan untuk berunding dalam segala masalah sulit dan pelik yang dihadapi oleh tokoh satrianya. Di samping itu kelompok wayang ini dinamakan wayang dagelan, karena kelompok wayang ini senantiasa dijadikan alat untuk ndagel (melawak) oleh dhalang. Punakawan secara umum terdiri dari empat tokoh dengan berbagai karakter yang unik di dalamnya. Ada Semar, Petruk, Nala Gareng dan juga Bagong. Menilik pada karakter yang ada, Semar digambarkan sebagai sosok manusia yang bijaksana dan kaya akan ilmu pengetahuan baik yang kasat mata maupun yang gaib, serta memiliki sumbangsih besar pada para majikannya melalui petuah-petuah yang disampaikan, meski kadang dengan gaya bercanda (Kresna 24).

Dalam seni pewayangan kehadiran Semar sangat diidolakan oleh para penonton. Pikiran, ucapan dan tindakan Semar dianggap pantas untuk diperhatikan, diteladani dan diterapkan dalam kehidupan sehari-hari. Masyarakat Jawa memberi apresiasi yang tinggi kepada tokoh Semar yang mampu memberi inspirasi untuk menuntun langkah pada jalan kebaikan.

Bentuk wayang merupakan penggambaran tentang sifat dan karakter manusia dalam wujud perlambangan. Wayang sebagai salah satu bukti dalam sejarah budaya Indonesia yang mencerminkan kesinambungan tradisi hasil dari transformasi budaya yang menjadi ciri budaya Indonesia. Wayang sebagai karya seni pertunjukan ini mengandung berbagai nilai karena sifatnya yang multimedia. Ini memberikan gambaran bahwa seni yang regius berubah menjadi seni sebagai dakwah (ajaran atau tuntunan) dan sebagai seni pertunjukan (tontonan). Maka seni setelah periode Islam dapat disebut sebagai tuntunan dan tontonan. 
Bentuk adalah struktur atau komposisi merupakan tata susun yang terdiri dari pengulangan atau susunan pola. Pola terdiri dari motif utama, motif pengisi (selingan), dan motif isian (isen).

1. Motif utama, merupakan unsur pokok berupa gambar-gambar dari wujud tertentu. Motif utama karena merupakan unsur (elemen) pokok maka sering disebut ornament pokok (ornamen utama). Pada kesenian klasik, motif utama merupakan motif yang mengandung falsafah atau ajaran (tuntunan).

2. Motif pengisi (motif selingan), merupakan unsur pendukung, berupa gambr-gambar dari bentuk tertentu, dibuat untuk mengisi bidang di antara motif utama atau diantara pola batik. Motif pendukung lebih kecil dari motif utama, fungsinya untuk melengkapi tata susun dalam pembuatan pola.

3. Isen (isian), merupakan unsur pengisi yang fungsinya menghias motif utama maupun motif selingan (pendukung). Motif ini pada seni rupa biasanya berupa titik-titik, garis-garis, gabungan titik, dan garis (Kartika 43-44).

Dalam wayang terdapat wanda yang berarti pengejawantahan bentuk wayang-wayang yang menggambarkan watak dasar. Konsepsi tentang ekspresi wajah dalam seni rupa wayang purwa dikenal dengan istilah wanda. Dengan kata lain wanda adalah varian (ragam) visual suatu wajah tokoh wayang dengan prejengan (karakter visual dasar wajah) tertentu karena suatu keadaan tertentu yang sedang dialaminya (muda, tua, marah, sedih, gembira, lega, dll) (Ahmadi 16).

Setiap lakon dalam pewayangan merupakan refleksi kehidupan. Arti dari lakon dalam kamus bahasa Jawa adalah cerita (Sudarmanto 166). Lakon berarti kisah yang didramatisasi dan ditulis untuk dipentaskan oleh sejumlah pemain di depan public. Artinya bahwa lakon merupakan padanan kata dari drama (Brahim 52; Sudjiman 46). Dalam seni pedalangan pengertian lakon tergantung pada konteks pembicaraannya. Kurang lebih ada tiga pengertian lakon, yaitu (1) lakon dapat berarti tokoh utama pada keseluruhan cerita wayang yang ditampilkan, (2) alur cerita yang tersirat, dan (3) lakon yang merujuk dari judul cerita yang akan disajikan (Kuwato 6). Lakon berarti kisah yang didramatisasi dan ditulis untuk dipentaskan oleh sejumlah pemain di depan public. Dalam pertunjukannya, setiap tokoh memiliki wanda-nya sendiri. Hal ini ditandai dengan bentuk visual posisi wajah, warna kulit, busana, atribut dan lainnya. Semar sering ditampilkan sebagai tokoh yang selalu memancarkan nilai-nilai kebijaksanaan hidup. Para satria utama mendapat wejangan dari Semar agar tercapai segala cita-citanya. Fungsi Semar memang sebagai penasehat dan hamba sahaya yang sangat setia.

Hubungan antara peran Semar dengan lakon yang dipertunjukan sangat erat hubungannya dengan wanda Semar yang digunakan. Maka, disini penulis ingin mengkaji dan mengungkap konsep trep pada Semar. Konsep trep ini akan terbukti apabila peran Semar pada satu lakon tertentu menggunakan wanda yang memiliki fungsi yang sama dan yang mendukung peran Semar pada lakon tersebut.

\section{Metode}

Penelitian ini merupakan penelitian studi literatur dengan mengkaji literatur berupa buku, jurnal dan rekaman pagelaran wayang melalui media sosial yang berhubungan dengan wayang Semar. Hasil dari kajian literatur ini akan menghasilkan konsep trep atau kesesuaian antara lakon Semar dengan wanda yang digunakan. 


\section{Hasil dan Pembahasan}

\section{Konsep Figur Semar}

Tokoh Semar dalam budaya Jawa kompilasi antara wayang, dan mitologi. Ideologi Jawa secara umum yang sinkretik menyebabkan Semar diinterpretasi oleh pendukung wayang bermacam-macam antara lain sebagai dewa, manusia, danyang, jin, bahkan dhemit. Secara umum Semar dianggap titisan Hyang Ismaya. Dalam pedalangan Semar sering disebut dewa ngejawantah. Artinya, dewa yang berwujud manusia (Solichin et al. 100).

Dalam Kamus Besar Bahasa Indonesia figur mempunya dua arti yaitu yang pertama wujud atau bentuk, dan yang kedua figur bisa diartikan tokoh. Tokoh di sini sebagai sosok yang menjadi peran utama. Sosok Semar dalam bentuk manusia cebol, lingkar perut dan bokong yang berukuran sama, memiliki dada besar seperti wanita, wajah dengan mata sedih berair, bibir selalu senyum, di kepala memiliki jambul, selalu menggunakan carik atau kain motif kawung, jari telunjuk tangan kiri menunjuk ke bawah dan tangan kanan mengepal kebelakang. Tatapan lurus ke depan.

Pendapat Ki Waluya mengenai Semar, Togog dan Betara Guru, disarikan sebagai berikut: "Penggambaran Semar dalam bentuk manusia cebol, adalah suatu penggambaran semu akan jiwa dan watak manusia dan gambaran dari kehidupan seisi jagad raya. Suatu gambaran akan keadaan zaman yang sebenarnya. Bentuk tubuhnya yang bulat seperti elips, merupakan gambaran dari bentuk dunia, demikian juga bentuk dari perut dan pantat yang hamper sama besar memberi satu gambaran, bahwa dunia ini dipecah menjadi dua bagian, Barat dan Timur (Pantat dan Perut). Suatu pembagian yang antara titik pusar dan dubur tidak akan bertemu satu dengan lainnya, ini merupakan suatu gambaran, suatu perlambang bahwa diantara Barat dan Timur tidak akan pernah menjadi satu, baik dalam bentuk falsafah, ideologi maupun kebudayaannya." (Mulyono 51)

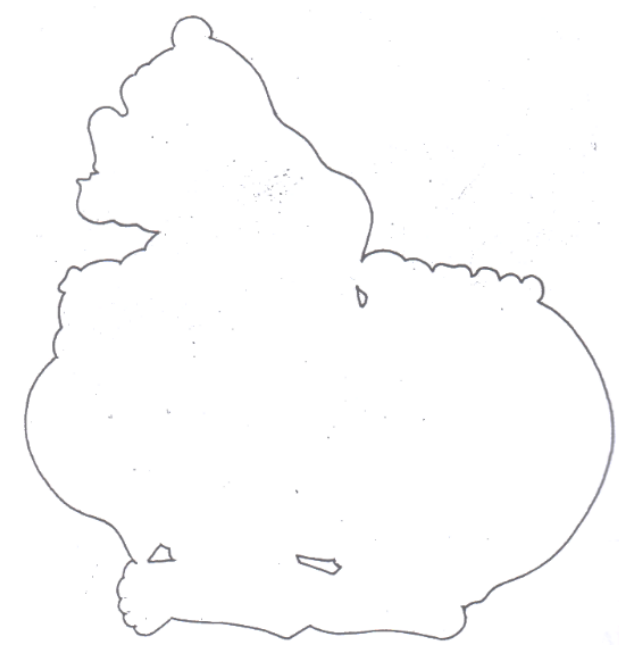

Gambar 1 Gatra Semar Sumber : Reprofile, Sunarto (156)

Bentuk wayang yang dimaksud sebagai bentuk/wujud dasar penciptaannya, yaitu merupakan penggambaran dari stilasi perwuujudan manusia, hewan, tumbuhan, benda dan gabungannya. Bentuk (wujud) merupakan sumber kedua yang lebih mengarah pada pengolahan bentuk tokoh-tokoh. Sedangkan busana terkait erat dengan kedudukannya seperti busana dewa 
kebanyakan berbaju jubahan; raja biasanya bermakutha, dan sebagainya. Oleh karena itu, dalam penggolongan ini dipilih ciri-ciri khusus yang lebih menonjol antara busana dan kedudukannya (Sunarto 56).

Bentuk wayang atas dasar pakem yang menjadi panutan bagi setiap pekria wayang menjadi tiga bagian pokok yaitu:

1. Bagian atas; kepala dan leher berikut segala kelengkapannya (mahkota, gelung, rias kepala, sumping, cunduk, kalung, subang)

2. Bagian tengah; lengan dan badan berikut segala kelengkapannya (kelat bahu, gelang, praba, pakaian/ busana, sabuk)

3. Bagian bawah; mulai pinggang hingga kaki, dengan segala kelengkapan busana dan juga berbagai hiasannya (Toekio dalam Pratama 8).

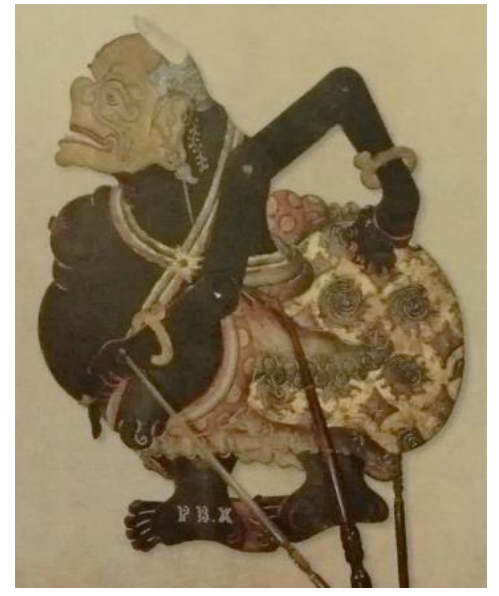

Gambar 2 Semar

Wayang Kulit Purwa Gagrag Surakarta (koleksi Ki Begug Poernomosidi)

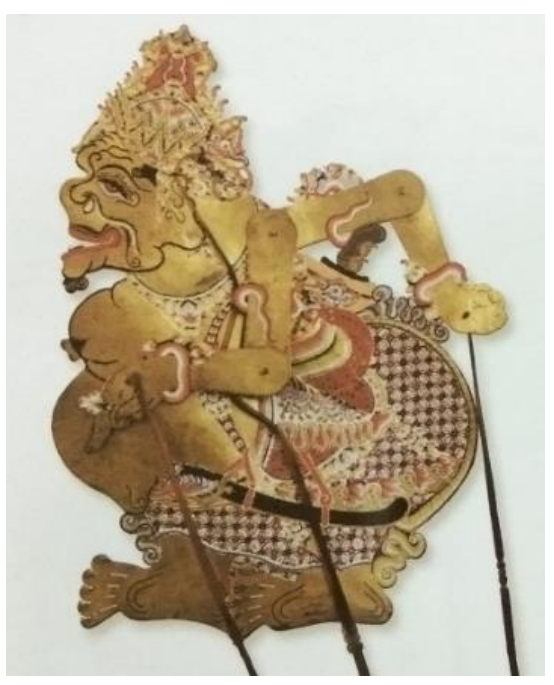

Gambar 4 Semar menjadi Raja Wayang Kulit Purwa Gagrag Surakarta (koleksi Istana Anak-anak TMII)

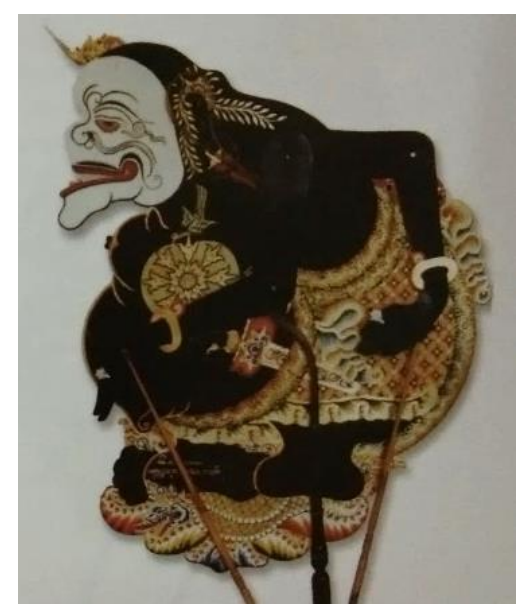

Gambar 3 Semar Respati Wayang Kulit Purwa Gagrag Surakarta (koleksi Bambang Suwarno) 
Keunikan pengambaran wayang tidak hanya dilihat dari postur atau wujudnya tetapi juga dilihat pada pengambaran busana atau atributnya, sehingga mellaui atribut busana ini dapat diketahui tingkat sosial dari tokoh wayang. Peran Semar sebagai raja menggunakan makutha, klat bahu, menggunakan kalung ulur-ulur, gelang, cincin dan anting lombok, sedangkan Semar yang berperan sebagai rakyat hanya menggunakan gelang, cincin dan anting Lombok. Ini berarti Apabila terdapat wayang kulit yang berbentuk perut dan bokong besar memiliki lingkar yang hampir sama, cebol, dengan kuncung di kepala maka itu tokoh Semar. Apabila terdapat wayang menggunakan makutha, klat bahu, kalung ulur-ulur, gelang cincin dan anting Lombok maka disebut Semar berperan sebagai raja. Apabila wayang kulit hanya menggunakan gelang, cincin dan anting Lombok maka disebut semar berperan sebagai rakyat. Perbedaan Semar sebagai rakyat, dewa dan raja terletak pada atribut dan busana atau carik yang digunakan.

\section{Konsep Trep}

Dalam pertunjukan wayang terdapat adegan gara-gara dan Semar berperan di dalamnya. Gara-gara dapat berarti keributan, kegemparan, kehebohan. Gara-gara dalam pertunjukan wayang merupakan pertanda peralihan situasi, gara-gara terjadi sekitar pertengahan lakon. Hampir semua lakon yang dipergelarkan dalam pertunjukan wayang kulit purwa Jawa pasti ada adegan gara-gara. Semar memiliki peran pada setiap lakon pewayangan, ada yang lakon khusus Semar atau sebagai peran utama ada juga yang Semar hanya sebagai peran pendukung.

Lakon-lakon Semar diantaranya: Beberapa lakon yang melibatkan tokoh Semar diantaranya adalah Kilat Buana, Tali Rasa Rasa Tali dan Talibuana, Gatutkaca Sungging, Semar Gugat, Semar Minta bagus, Bathara Wisnu Krama, Semar tambak, Manumayasa Rabi, Pandu lahir, Pandu karma, Mintorogo, Semar Kuning/Badranaya, Semar mbangun Klampis Ireng, Semar mbangun Khayangan, Semar mbarang jantur dan banyak lagi.

Semar dalam pertunjukan wayang memiliki 3 (tiga) peran yaitu: Semar sebagai dewa, Semar sebagai raja dan Semar sebagai rakyat. Istilah peran dalam "Kamus Besar Bahasa Indonesia" mempunyai arti pemain sandiwara (film), perangkat tingkah yang diharapkan dimiliki oleh orang yang berkedudukan di masyarakat. Pengertian peran yaitu peran merupakan aspek dinamis kedudukan (status), apabila seseorang melakukan hak dan kewajibannya sesuai dengan kedudukannya, maka ia menjalankan suatu peranan.

Menurut Suwarno, dkk dalam artikel dengan judul Kajian Bentuk dan Fungsi Wanda Wayang Kulit Purwa Gaya Surakarta, Kaitannya dengan Pertunjukan, wanda wayang yaitu:

Proses transformasi dari deskripsi pewayangan yang divisualisasikan ke dalam bentuk figur wayang purwa disebut wanda wayang purwa. Setiap tokoh wayang purwa memiliki ciri figur tersendiri, yang dalam pewayangan disebut wanda yakni bentuk secara keseluruhan dari ujung rambut sampai telapak kaki, termasuk tata busana, aksesoris, unsur garis (corekan dan kapangan) dan tata warna (sunggingan). Wujud figur wayang tidak sekedar melukiskan tokoh tetapi juga melukiskan karakter (Suwarno et al. 2).

Dalam pewayangan, tokoh wayang Semar memiliki banyak wanda wayang. Beberapa wanda yang sudah ditemukan diantaranya adalah Semar wanda Ginuk, Dumuk, Brebes dan Miling untuk wayang gaya Surakarta (Solichin et al. 1176; Sunarto 18). Di samping keempat wanda itu, Semar juga memiliki wanda dukun untuk wayang gaya Yogyakarta. Masing-masing wanda tersebut biasa digunakan untuk mencapai suasana atau kesan tertentu dalam suatu adegan tertentu pula, walaupun tokohnya sama. Dalam pertunjukan wayang penggunaan wayang 
dengan wanda satu berbeda dengan wanda lainnya, misalnya: adegan jejer berbeda wandanya dengan waktu marah atau perang. Penggunaan wanda Semar pada pertunjukan wayang disesuaikan dengan waktu, misalnya pertunjukan wayang dimainkan di waktu sore, wayang Semar yang digunakan ialah yang mukanya dan seluruh badannya bercat prada dan sewaktu di mainkan menjelang pagi yang digunakan ialah wayang yang mukanya bercat putih dan badannya bercat hitam. Di mana Semar dimainkan bersama dengan kedua orang anaknya, Gareng dan Petruk, maka Semar berwanda: 1. Gilut, 2. Dunuk, 3. Watu, 4. Mega, 5. Dukun, 6. Ginuk, 7. Miling, dan 8. Brebes (Hardjowirogo 226).

Menurut Darman Gandadarsana, ciri-ciri wanda wayang dapat dilihat dari corekan, kapangan, tatahan, bedhahan, sunggingan, dan gapitan (Sunarto 18). Wanda wayang kaitannya dengan corekan adalah penamaan wanda wayang yang didasarkan pada pola sketsa dan busana. Kapangan adalah bentuk luar atau bodi wayang, yang dapat menentukan sifat visualisasi bentuk wayang yang digambarkan menurut proporsinya: gagah, halus, gecul, kenes, tangkas, dan sebagainya.

Tatahan wayang sangat ditentukan oleh ukuran besar-kecil, karakter wayang itu sendiri, dan kelembutan pola tatahan. Pola-pola tatahan wayang umumnya memiliki kesamaan, misalnya: mas-masan untuk perhiasan, seritan untuk rambut, tratasan dan bubukan untuk bentuk garis. Bedhahan wayang sangat menentukan karakter tokoh karena berfokus pada ekspresi wajah tokoh wayang yang dilukiskan. Sunggingan atau pewarnaan wayang pada masing-masing daerah mempunyai ciri khas tersendiri. Gapitan wayang kulit pada dasarnya berfungsi memberikan kekuatan pada wayang yang bersangkutan serta sebagai tangkai pegangan (Sunarto 18-19).

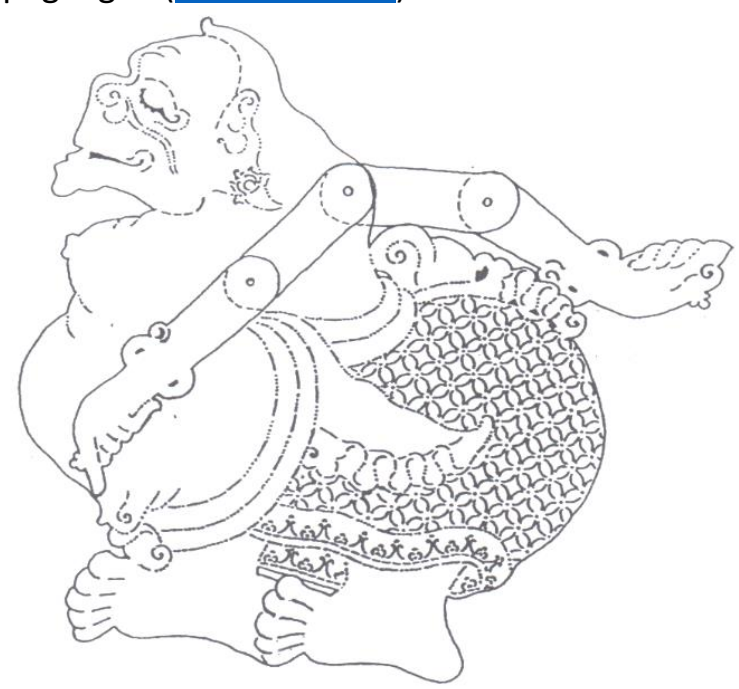

Gambar 5. Bentuk Tatahan Semar

Sumber : Reprofile, Ahmadi (146)

Keterangan ciri-ciri wujud wanda tergantung para seniman dalang yang memahaminya, sedang terbentuknya wanda wayang kemungkinan pada saat mbedah wayang atau meterani yaitu ingin membuat wayang Semar yang baru dengan cara ngeblat dengan menggaris/mempola pada bentuk luar wayang lama, kemungkinan sedikit bergeser, sehingga dapat terjadi dan menyebabkan kesan penanggap juga berbeda-beda.

Keunikan dalam penggambaran wayang tidak saja pada posturnya, tetapi ada juga pada penggambaran busana atau atributnya, sehingga melalui atribut busana ini dapat diketahui tingkat sosial dari tokoh wayang (Sunarto 20). Berdasar dari pengertian umum, lakon sering 
disamakan dengan cerita. Lakon berarti kisah yang didramatisasi dan ditulis untuk dipentaskan oleh sejumlah pemain di depan public. Artinya bahwa lakon merupakan padanan kata dari drama (Brahim 52; Sudjiman 46). Dalam seni pedalangan pengertian lakon tergantung pada konteks pembicaraannya. Kurang lebih ada tiga pengertian lakon, yaitu (1) lakon dapat berarti tokoh utama pada keseluruhan cerita wayang yang ditampilkan, (2) alur cerita yang tersirat, dan (3) lakon yang merujuk dari judul cerita yang akan disajikan (Kuwato 6).

Kata lakon merupakan bentukan kata dari laku dan mendapatkan akhiran an, dalam Bahasa Jawa yang berarti tindak tanduk atau acting. Peristiwa nyata atau rekaan yang disampaikan dengan tindak-tanduk melalui manusia atau benda mati sebagai penggantinya. Agar terjalin komunikasi dengan publik, lakon dilengkapi dengan dialog dan monolog serta iringan, seperti tata suara, gamelan, dan tata cahaya (Shadily 43).

Peran Semar pada lakon-lakon pewayangan sangar unik, karena peran Semar yang hanya sebagai abdi dalem sangat di hormati oleh tuannya. Misalnya dalam lakon Kilat Buana Semar ingin dibunuh oleh Arjuna atas perintah Dewa Guru karena dianggap sebagai ancaman bagi Dewa Guru, lakon Semar Mbangun Kahyangan dalam lakon ini sebagai yang hanya sebagai abdi sangat dihormati oleh Pandawa bahkan oleh Dewa, lakon Makuta Rama disini Semar menjadi penolong Arjuna dari Batara Guru, dibawah ini lakon Laire Ismoyo atau Lahirnya Semar dalang Ki Purbo Asmoro. Pemilihan dalang Ki Purbo Asmoro yakni dengan mempertimbangkan kapasitasnya sebagai dalang yang sering sekali memainkan lakon Semar dan sangat mumpuni. Selain itu, Purbo Asmoro adalah seorang tenaga pengajar (dosen) di Jurusan Pedalangan Institut Seni Indonesia (ISI) Surakarta. Hal ini menunkukkan kualitas inteltualnya.

Pada lakon ini adanya pertentangan perebutan warisan. Di awali Tejamaya yang tidak terima karena Manikmaya dianggap sebagai penguasa tri loka, lalu terjadilah perebutan kekuasaan yang lebih berhak sebagai penguasa tri loka antara Tejamaya, Ismaya dan Manikmaya. Karena pertikaian tak kunjung selesai maka Manikmaya mengusulkan untuk diadakan adu kesaktian, barang siapa yang bisa menelan gunung dan mengeluarkannya kembali maka dialah yang akan menjadi pemimpin di Triloka. Babak di bawah ini adalah babak dimana Ismaya menelan gunung dan dia berhasil menelannya tetapi berhenti sampai di perut dan tidak bisa mengeluarkannya kembali.

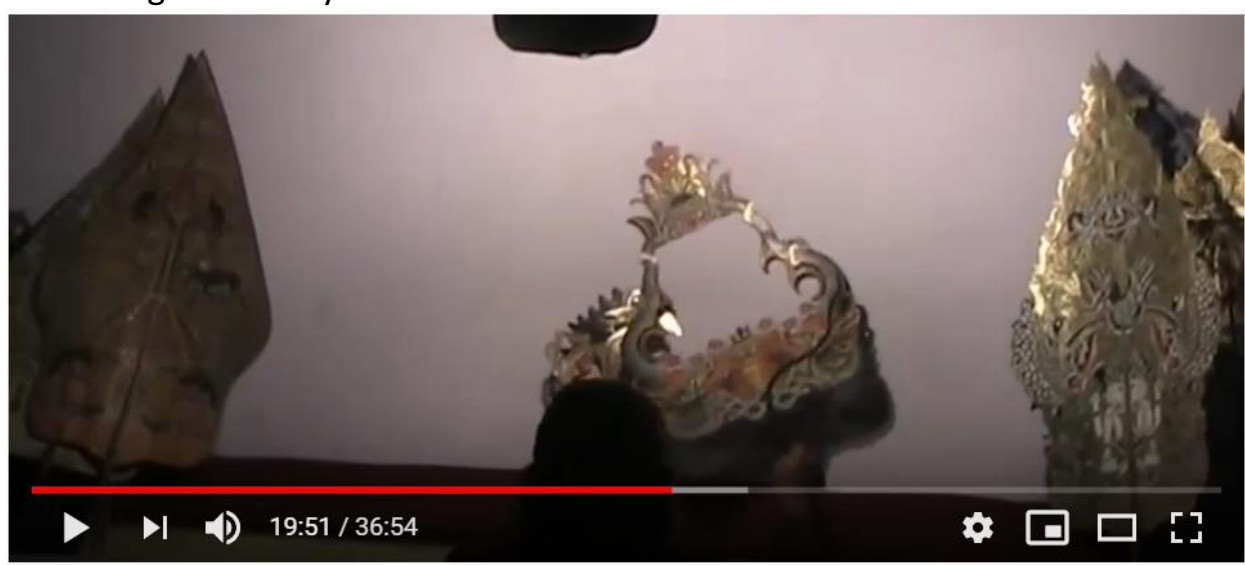

Gambar 6 Babak Ismaya menelan gunung

Sumber : https://www.youtube.com/watch?v=1UWeYM4rj5g\&t=1241s

Sedangkan babak di bawah ini adalah babak dimana Ismaya berubah menjadi Semar. Bentuk Ismaya berubah karena Ismaya tidak bisa mengeluarkan kembali gunung yang ditelannya menyebabkan perutnya besar dan ujung gunung pun menyodok ke bagian pantat, sehingga pantatnya pun membesar. Ismaya turun ke bumi dan berubah menjadi Semar dengan tugas 
menjaga ketertiban dunia, dan menjadi pamong bagi para raja atau para kesatria yang berjiwa mulia. Selain itu, Sang Hyang Tunggal juga mempercayakan Ismaya sebagai pamong sejati serta mengemban kewajiban menentramkan dunia dengan mengajak setiap manusia untuk berbuat baik.

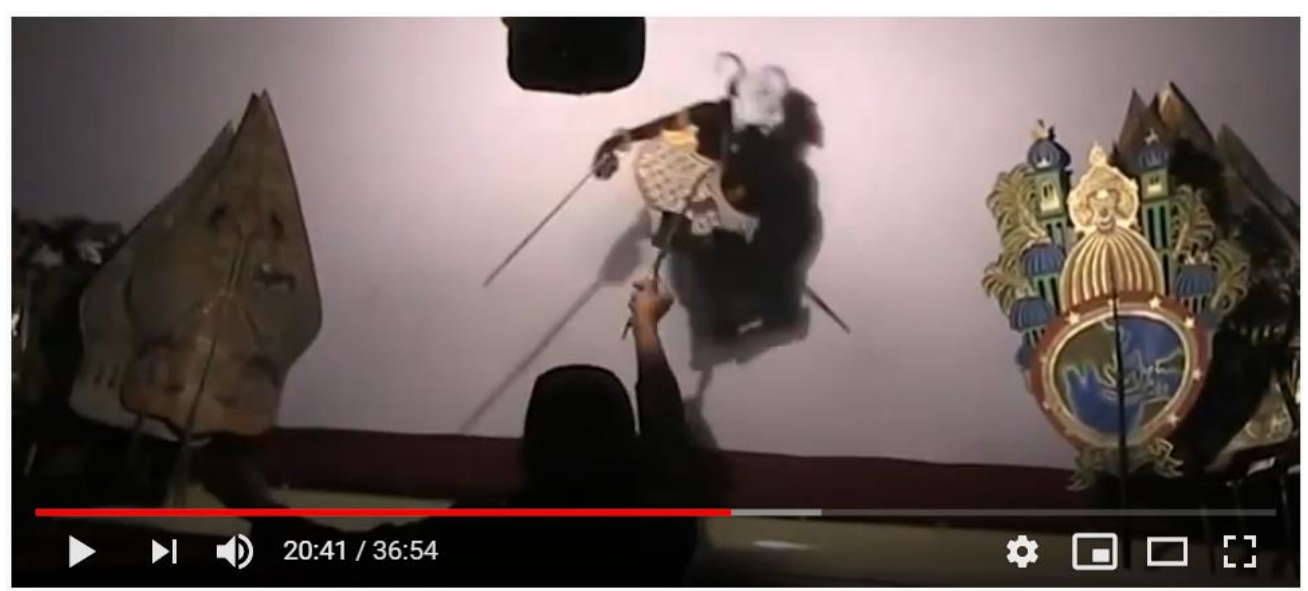

Gambar 7 Babak Ismaya setelah berubah menjadi Semar

Sumber : https://www.youtube.com/watch?v=1UWeYM4rj5g\&t=1241s

Pada lakon Laire Semar penggunaan wanda sesuai dengan peran Semar yang berubah sebagai rakyat atau abdi, ini terlihat dari atribut dan busana yang digunakan Semar pada saat turun ke dunia. Ini terlihat dari penggunaan carik atau kain yang bermotif kawung, pada pewayangan motif kawung melambankan rakyat jelata atau abdi, atribut yang digunakan juga hanya gelang dan klat bahu. Dapat ditarik kesimpulan hubungan antara peran, lakon dan wanda terjadi apabila wanda Semar yang digunakan dengan peran yang dimainkan sesuai dan menyatu dengan lakon yang dipertunjukan maka terjadi trep atau sesuai diantara ketiganya. Jadi, konsep trep pada lakon Laire Semar ini terbukti.

\section{Simpulan}

Semar dalam pertunjukan wayang memiliki peran sebagai dewa, raja dan rakyat atau abdi. Peran Semar tergantung pada lakon yang dimainkan, baik dalam lakon Semar sebagai peran utama maupun sebagai pendukung. Semar memiliki beberapa wanda diantaranya wanda Ginuk, Dumuk, Brebes dan Miling. Munculnya wanda pada Semar karena kebutuhan lakon dan pada saat ngeblat terjadi pergeseran yang menyebabkan wanda berbeda. Bentuk-bentuk wanda yang digunakan disesuaikan dengan kebutuhan lakon yang dibawakan oleh dalang. Hasil telaah pada pertunjukan Laire Ismaya dengan dalang Ki Purbo Asmoro terjadi kesesuaian antara lakon, peran dan wanda yang digunakan. Konsep kesesuaian penggunaan wanda untuk peran tertentu pada lakon pertunjukan wayang tertentu pula, konsep ini disebut dengan trep. Disebut trep apabila peran wayang Semar dalam suatu lakon pewayangan menggunakan wanda yang sesuai dengan fungsi peran tersebut. Hasil dari penelitian ini melalui telaah pertunjukan Laire Semar dengan dalang Ki Purbo Asmoro berhasil menemukan konsep trep pada lakon Semar. Indikator dari Semar trep antara lain:

1. Peran Semar sesuai dengan lakon yang dimainkan.

2. Semar berperan pada lakon punakawan dan lakon lainnya. 
3. Atribut dan bentuk yang digunakan salah satu wayang menjelaskan wanda wayang tersebut.

\section{Daftar Pustaka}

Ahmadi, Agus. Kriya Wayang Kulit Purwa Gaya Surakarta Identifikasi Pola, Aneka Tatahan Dan Sunggingannya. ISI Press Surakarta, 2016.

Aisah, Aeiny Nur. "Kontruksi Sosial Nilai Psikologi Punakawan Semar Pada Masyarakat Jawa." vol. Sarjana, Skripsi, Universitas Muhammadiyah Surakarta., 2008.

Brahim. Drama Dalam Pendidikan. Gunung Agung, 1968.

Hardjowirogo. "Sejarah Wayang Purwa." 1982.

Kartika, Dharsono Sony. Estetika Nusantara. ISI Press Surakarta, 2015.

Kresna, Ardian. Punakawan: Simbol Kerendahan Hati Orang Jawa. Narasi, 2012.

Kuwato. "Tinjauan Pakeliran Padat Palguna Palgunadi Karya Bambang Ds." 1990, p. 6.

Mulyono, Sri. Apa Dan Siapa Semar. CV. Haji Masagung, 1989.

Pratama, Dendi. "Wanda Figur Gatotkaca Dalam Pertunjukan Wayang Kulit Purwa Gaya Surakarta." vol. Doktor, Disertasi, institut Seni Indonesia Surakarta, 2019.

Shadily, Hasan. Ensiklopedi Indonesia Jilid 1. Ichtiar Baru, 1980.

Solichin et al. Ensiklopedi Wayang Indonesia. Revisi edition, Mitra Sarana Edukasi, 2017.

Sudarmanto. Kamus Lengkap Bahasa Jawa. Widya Karya, 2017.

Sudjiman, Panuti. Kamus Istilah Sastra. Gramedia, 1984.

Sunarto. Seni Gatra Wayang Kulit Purwa. Dahara Prize, 1997.

Suwarno, Bambang et al. "Kajian Bentuk Dan Fungsi Wanda Wayang Kulit Purwa Gaya Surakarta, Kaitannya Dengan Pertunjukan." Gelar Jurnal Seni Budaya, vol. 12, no. 1, 2014, pp. 1-10, doi:https://doi.org/10.33153/glr.v12i1.1487. 